\title{
Exploitation of Botanicals for Eco-Friendly Management of Grape (Vitis vinifera L.) Anthracnose caused by Elsinoe ampelina
}

\author{
Nithin B. Patil ${ }^{1 *}$, Sunil Zacharia ${ }^{1}$ and Gopu Ajay ${ }^{2}$ \\ ${ }^{1}$ Department of Plant Pathology, Sam Higginbottom University of Agriculture \\ Technology and Sciences, Allahabad - 211007, India \\ ${ }^{2}$ Assam Agriculture University, Jorhat, Assam, India \\ *Corresponding author
}

\begin{abstract}
A B S T R A C T
Keywords

Anthracnose,

Botanicals, Elsinoe ampelina

\section{Article Info}

Accepted:

16 April 2018

Available Online:

10 May 2018

Grape (Vitis vinifera L.) is a fruit, botanically a berry, is among the oldest plants on earth and is one among the most consumed fruit crop worldwide. India is ranked at $9^{\text {th }}$ position in grape production (Shikamany, 2001; Gade et al., 2014). It is affected my numerous pest and disease. Anthracnose is a major disease following powdery mildew and downy mildew for which excessive chemicals are used for their management causing potential threat. In order to reduce the damage to the environment and humans, an attempt was made to study the antagonistic property of seven botanicals viz., Azadirachat indica, Allium sativum L., Allium cepa L., Eucalyptus teretecornes, Parthenium hysterophorus, Pongamia pinnata and Ocimum basilicum for the management of anthracnose of grape popularly known as "Bird's eye spot" caused by E. ampelina. All the above mentioned seven botanicals were tested by poison food technique against E. ampelina. Among the botanicals tested the maximum per cent mycelial inhibition was recorded in treatments involving Onion extract $(78.00 \%)$ and Garlic extract $(72.23 \%)$ at 10 per cent concentrations which was found to be significantly superior over rest of the treatments.
\end{abstract}

\section{Introduction}

Grape (Vitis vinifera L.) is a fruit, botanically a berry, is among the oldest plants on earth. India being the major producer of grapes, production suffers from biotic and abiotic stresses. Biotic stress such as anthracnose is a fungal disease caused by Elsinoe ampelina is also referred as "Bird's eye spot" is a major disease following powdery mildew and downy mildew.

The disease was first referred by Pliny in Italy on the $1^{\text {st }}$ century of Christian era and later reported by Burrill during 1886 from Illinois, U.S.A. It was observed that the disease was present in Europe for centuries and was introduced into the United States through cuttings / young vines from European grapes. In India, the disease was first recorded in 1903 near Pune (Butler, 1905). The disease is widely prevalent in Maharashtra, Karnataka, Punjab, Haryana and Andhra Pradesh.

The disease affects all the aerial parts in the green stage, mostly on the new shoots and fruits. On leaves small circular to irregular, 1$5 \mathrm{~mm}$ dia. in size, dark brown spot appear 
which later turn gray in the center and dark brown at the margins. The central necrotic tissue often falls off leaving a shot-hole appearance. In severe cases the complete driving of leaves is also noticed. On shoots and tendrils, small isolated brown spots develop which elongate to from elliptical, slightly sunken lesions. Later, the central area of the lesion develops into ashy-gray colour bordered by darker rim. The affected shoots may be restricted in growth as well as shedding of inflorescence / flower buds takes place due to infection. On berries, typical bird's eye spot symptoms appear having violet to gray center and dark brown margins.

In the recent years, there has been major thrust on residue free, organic grape production. In view of this, different botanicals, bio-agent and bio-rational need to be explored for their effectiveness and to fit in with the management schedule of the disease suitably.

\section{Materials and Methods}

\section{Collection, isolation and maintenance of the pathogen}

Grape leaves and shoots which had symptoms of anthracnose were collected from the grape vineyard and other grape growing areas during the survey and were used for isolation of the fungus in vitro. The diseased samples were washed thoroughly under the tap water and allowed to dry in shade under laboratory conditions. The infected portion along with some healthy part was cut into small pieces, and surface sterilized and then transferred aseptically to Petri plates containing Potato Dextrose Agar (PDA) media. The inoculated Petri plates were then incubated at $28 \pm 1^{\circ} \mathrm{C}$ and growth of fungus and were observed periodically. The pure colonies that developed from these infected leaf/stem bits was transferred onto the PDA slants aseptically. The fungus was sub cultured on PDA slants and allowed to grow at $28 \pm 1^{\circ} \mathrm{C}$ for one week and such slants were preserved in refrigerator at $4^{\circ} \mathrm{C}$ and were renewed once in two months. The preserved culture was used for further studies.

\section{Preparation of cold aqueous and organic extracts}

Fresh plant materials were collected and washed in fresh tap water and then in distilled water. Hundred grams of fresh sample was chopped and crushed in a surface sterilized pestle and mortar by adding $100 \mathrm{ml}$ sterile water $(1: 1 \mathrm{w} / \mathrm{v})$. The extract was filtered through two layers of muslin cloth. Finally such obtained extract was used as stock solution. To study the antifungal mechanism of plant extracts, the poisoned food technique was used (Nene and Thapliyal, 1973). Five and ten ml of stock solution was mixed with 95 and $90 \mathrm{ml}$ sterilized molten PDA medium, respectively so as to get 5 and 10 per cent concentration. The medium was thoroughly shaken for uniform mixing of extract. Twenty $\mathrm{ml}$ of medium was poured into sterile petri plate, mycelium disc of five $\mathrm{mm}$ size from periphery of actively growing culture was cut out by sterile cork borer and one such disc was placed at the center of each plate without containing any extract. Controls were maintained by growing the pathogen on PDA plates. Then such plates were incubated at $28 \pm 1^{\circ} \mathrm{C}$ and radial growth was taken when maximum growth was observed in control plate. The efficacy of plant products or botanicals was expressed as per cent inhibition of radial growth over the control which was calculated by using Vincent (1947) formula.

\section{Results and Discussion}

As plant extracts are cost effective means of management, an effort was made to know the efficacy of different plant extracts against $E$. ampelina. Seven botanicals were evaluated 
against E. ampelina (Table 1). This was carried out by adopting the "poisoned food technique' as described in "Material and Methods". Results revealing the effects of plant extracts on per cent inhibition of $E$. ampelina are presented in the table 2 . Among the Seven botanicals tested at two concentrations $(5 \%$ and $10 \%)$ the maximum per cent mycelial inhibition was recorded in treatments involving Allium cepa L. (78.00\%) and Allium sativum L (72.23\%) at 10 per cent concentrations which was found to be significantly superior over rest of the treatments and it was followed by Oсітит basilicum $(51.92 \%)$ at 10 per cent.

The least inhibition of mycelial growth was observed in Eucalyptus teretecornes (14.19\%) and Pongamia pinnata (14.53\%) at 5 per cent concentration.

Table.1 List of plant extracts

\begin{tabular}{|c|}
\hline SI. No. \\
\hline 1 \\
\hline 2 \\
\hline 3 \\
\hline 4 \\
\hline 5 \\
\hline 6 \\
\hline 7 \\
\hline
\end{tabular}

\section{Botanical name}

Azadirachta indica

Allium sativum $L$.

Allium cepa $L$.

Eucalyptus teretecornes

Parthenium hysterophorus

Pongamia pinnata

Ocimum basilicum

\section{Common name}

Neem

Garlic

Onion

Eucalyptus

Parthenium

Honge

Basil

\section{Part used}

Leaf

Bulb

Bulb

Leaf

Leaf

Leaf

Leaf

Table.2 In vitro evaluation of botanicals against E. ampelina

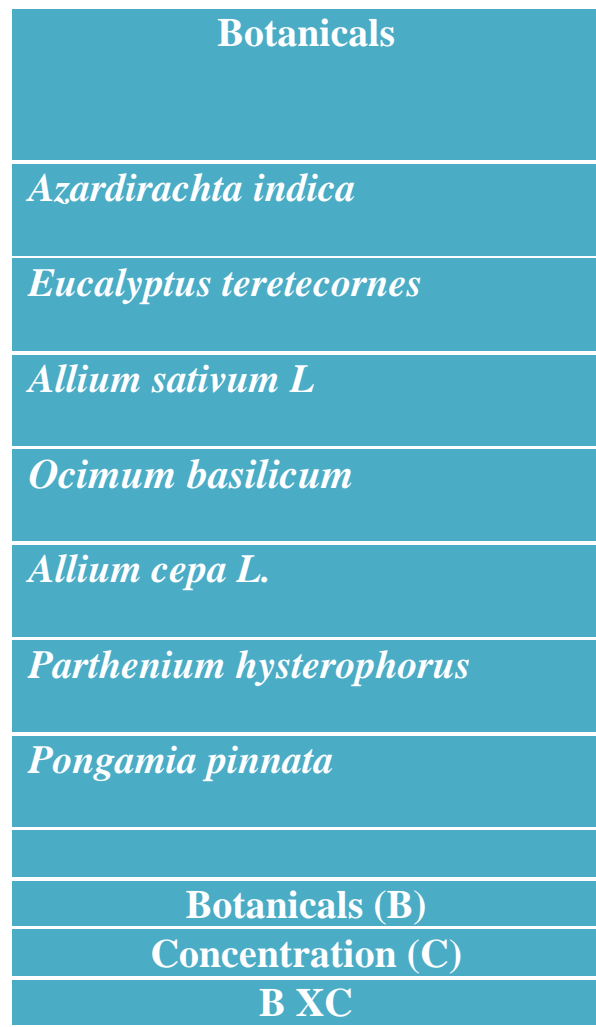

\begin{tabular}{|c|c|c|}
\hline \multicolumn{2}{|c|}{ Per cent inhibition of mycelial growth } & \multirow{2}{*}{ Mean } \\
\hline \multicolumn{2}{|c|}{ Concentration $(\boldsymbol{\%})$} & \\
\hline 38.97 & $\mathbf{1 0}$ & 45.30 \\
$(38.61)$ & 51.62 & $(42.11)$ \\
\hline 14.19 & $(45.61)$ & 20.00 \\
$(21.74)$ & 25.81 & $(26.84)$ \\
\hline 43.02 & $(31.95)$ & 57.63 \\
$(40.98)$ & 72.23 & $(49.60)$ \\
\hline 28.03 & $(58.22)$ & 39.97 \\
$(32.32)$ & 51.92 & $(39.11)$ \\
\hline 45.07 & $(45.91)$ & 61.54 \\
$(42.17)$ & 78.00 & $(52.10)$ \\
\hline 37.44 & $(62.03)$ & 41.62 \\
$(37.71)$ & 45.81 & $(40.14)$ \\
\hline 14.53 & $(42.58)$ & 18.55 \\
$(22.81)$ & 22.56 & $(25.98)$ \\
\hline S.Em. & $(29.16)$ & $\mathbf{C D} \mathbf{a t} \mathbf{1 \%}$ \\
\hline $\mathbf{0 . 5 4}$ & & $\mathbf{2 . 1 5}$ \\
\hline $\mathbf{0 . 2 8}$ & & $\mathbf{1 . 1 5}$ \\
\hline $\mathbf{0 . 7 7}$ & & $\mathbf{3 . 0 5}$ \\
\hline
\end{tabular}


Irrespective of concentration of plant extracts evaluated, the treatment involving Allium cepa $L$. was recorded maximum mean per cent mycelial inhibition (61.54\%) followed by Allium sativum L (57.63\%) and minimum mean mycelial inhibition was recorded in Pongamia pinnata (18.55\%).

In the present investigation, seven plant extracts were tested under in vitro condition against $E$. ampelina to know the fungitoxis mechanism of botanicals. Allium cepa $L$. $(78.00 \%)$ and Allium sativum L $(72.23 \%)$ at 10 per cent concentrations were found to maximize the inhibition of mycelial growth. Similar results were reported by Jamadar and Lingaraju (2011) stating that Onion extract $10 \% \quad(78.0 \%$ inhibition) was significantly superior and was at par with garlic extract $10 \%$ (72.2\% inhibition) against E. ampelina and leaf extract of eucalyptus and garlic bulbs at 10 per cent concentration gave higher level of inhibition of anthracnose disease of pomegranate caused by Colletotrichum gloeosporioides (Prashanth et al., 2008). In another study conducted by Kolase et al., (2014) stated that under in vitro condition neem leaves extract at 5 per cent concentration was found to inhibit the growth of Colletotrichum gloeosporioides.

\section{References}

Butler, E. J. 1905, Pilzkrankheiten in Indienim Jahre. Zeitsch fur Pflanzenkr, 15: 44-48.
Gade, A. D., Gaikwad, S. B., Gaikwad. N. S., 2014, Trends in production and exports of grapes in India. Indian Streams Research Journal, 4(2): 1-5.

Jamadar, M. M and Lingaraju, S., 2011, In vitro evaluation of fungicides, botanicals and bioagents against Elsinoeampelina an incident of anthracnose of grapevine. Karnataka journal of agricultural sciences, 24(2): 146-148

Kolase, S.V., Kamble, T.M., and Musmade, N.A., (2014) Efficacy of different fungicides and botanicals against blossom blight of Mango caused by Colletotrichun gloeosporioides. International Journal of Plant Protection. 7(2): 444-447

Nene, Y. L. and Thapliyal, P. N., 1973, Fungicide in Plant Diseases Control. Third Edition ; Oxford and IBH publishing Co. Pvt. Ltd., New Delhi, pp. 325.

Prashanth, Arun R Sataraddi, M K Naik, M B Patil and Rajesh S Patil (2008) Evaluation of Fungicides, Bioagents and botanicals Against Pomegranate Anthracnose. Indian journal of Plant Protection. 36: 283-287

Shikamany, S.D., 2001, Grape production in India. In: Papademetrion MK, Dent FJ (eds) Grape production in the Asia Pacific region, FAO RAP Publ, Bankok, Thailand, pp. 15-25.

Vincent, J. M., 1947, Distortion of fungal hyphae in presence of certain inhibitors. Nature, 159: 50.

\section{How to cite this article:}

Nithin B. Patil, Sunil Zacharia and Gopu Ajay. 2018. Exploitation of Botanicals for EcoFriendly Management of Grape (Vitis vinifera L.) Anthracnose caused by Elsinoe ampelina. Int.J.Curr.Microbiol.App.Sci. 7(05): 1754-1757. doi: https://doi.org/10.20546/ijcmas.2018.705.204 